\title{
ÓRFÃOS DO ELDORADO: CONFLUÊNCIAS IDENTITÁRIAS E CULTURAIS NA NARRATIVA DE MILTON HATOUM
}

\author{
Maria Alexandrina Félix de Andrade Silva ${ }^{1}$
}

RESUMO:

O presente artigo objetiva estudar a obra Órfãos do Eldorado, de Milton Hatoum, considerando, nessa singular narrativa, o espaço amazônico enquanto lugar de produção de sentidos diversificados. A partir da metaforização dos vocábulos "órfãos" e "eldorado", Hatoum sutilmente vai desvelando as confluências identitárias e culturais entre aqueles que residem na Amazônia, seja os nativos com seus "sistemas simbólicos próprios" ou os homens que aqui chegaram sequiosos de riqueza e poder. Discute-se aqui o espaço e o tempo enquanto elementos essenciais para a compreensão das marcas identitárias estabelecidas através da evolução histórica e literária dos povos nativos e sua nem sempre aceitação do convívio pacífico com o explorador. Pretende-se ainda investigar também alguns aspectos culturais principalmente ligados a família, hierarquia e a posse e perda de bens materiais e morais. Por intermédio de vozes "lacunares" a intenção é articular diferentes discursos entrecruzados, que se negam a se legitimam no "edifício familiar", também metafórico, enquanto reminiscência de um passado silenciado e abruptamente despedaçado pela modernidade.

PALAVRAS-CHAVE:

Espaço Amazônico. Cultura. Identidade. Discursos. Sentidos Diversificados.

\section{ELDORADOORPHANS:CULTURALANDIDENTITYCONFLUENCES ON MILTON HATOUM'S NARRATIVE}

\begin{abstract}
:
This article aims to study the work Eldorado Orphans by Miltom Hatoum, taking into account, in this unique narrative, the amazonian space as a place of production of diversified senses. From the metaphorization of the words "orphans" and "eldorado", Hatoum subtly discloses cultural and identity confluences among those who live in the Amazon, whether the natives with their own symbolical systems or other men who came up later thirsting for wealth and power. The discussion here is about space and time as essential elements for the comprehension of identity marks established through out the historical and literary evolution of the native peoples and their conflicts and acceptance of a

1 Mestra em Letras: Linguagem e Identidade - PPGLI/UFAC, 2016 e Professora dessa mesma Instituição Federal de Ensino, em convênio com o governo do Estado do Acre, atuando no campus da UFAC na cidade de Cruzeiro do Sul.

N. E.: Este artigo, publicado in memoriam da Professora professora Alexandrina Félix (falecida em fevereiro deste ano), é parte das reflexões que a mesma desenvolveu em sua Dissertação de Mestrado defendida no ano de 2016, junto ao Programa de Pós-Graduação em Letras: Linguagem e Identidade, sob a orientação do Professor Dr. João Carlos de Souza Ribeiro, com o título "Cotidiano e distanciamento: uma leitura de Órfãos do Eldorado, de Milton Hatoum".
\end{abstract}


pacific living with the explorer. We also aim to investigate some cultural aspects, especially those linked to family, hierarchy and the possession of material and moral assets. Mediated by "incomplete" voices, the idea is to articulate crisscrossed discourses which deny to legitimate themselves at the "family building", also metaphorical as a reminiscence of a silent past abruptly shattered by modernity.

KEYWORDS:

Amazonian Space. Culture. Identity. Discourse. Diversified Senses.

$\begin{array}{lll}\text { Ecrever sobre a em 1989, ele destaca-se na } \\ \text { Amazônia nos parece, } & \text { literatura } & \text { contemporânea }\end{array}$ à primeira vista, apenas brasileira como um intelectual uma tarefa fascinante. Mas diferenciado por conseguir ao iniciarmos uma leitura mais orientada sobre o tema percebe-se o emaranhado de documentos, narrativas, relatos, etc., uma enorme gama de informações que nos deixa a mercê de um jogo labiríntico de descrições, informações e dualismos a cerca da região estabelecidos por todos os que aqui vieram no bojo de um "processo exploratório", seja ele, "real ou ficcional". Por isso estudar a Amazônia, além de um exercício intelectual prazeroso é, acima de tudo, um compensador desafio.

Milton Hatoum é autor recente da nossa literatura de "expressão amazonense", recente porque sua obra iniciase no final dos anos noventa. Premiado desde sua estreia retrataremsuasobrasouniverso amazônico tão marcado pela diversidade cultural do seu povo, pela confluência de marcas identitárias que ali se estabelecem e principalmente por "sujeitos em trânsito", que desde sempre contribuem para determinar a riqueza étnica, social e intelectual da região.

Em sua obra, o romancista realiza uma verdadeira filtragem do cotidiano amazônico. Suas narrativas são calcadas em experiências pessoais e lugares, objetos e paisagens além de um estudo minucioso que vai dos clássicos mais antigos aos escritores modernos e contemporâneos da vasta literatura brasileira e principalmente sobre a Amazônia. Milton Hatoum 
é um intelectual do nosso tempo. Nasceu em Manaus em 1952, formou-se em Arquitetura em São Paulo, mas voltou a Amazônia depois de ir à Espanha e a França como bolsista, onde estudou literatura. $\mathrm{Na}$ Universidade Federal do Amazonas foi professor e participou de alguns projetos sociais. Também teve uma rápida passagem como professorvisitante de Literatura na Universidade de Berkeley, Califórnia, nos Estados Unidos. Além de professor e romancista é também tradutor e ensaísta, contista e colaborador como colunista em suplementos literários em algumas renomadas revistas como a Isto É, onde trabalhou por algum tempo.

A obra de Milton Hatoum é detentora de vários prêmios, já ganhou duas vezes o prêmio Jabuti e é considerado hoje o romancista brasileiro mais conceituado no nosso cenário literário. Suas obras e seus personagens são construídos a partir da articulação dos mais diferentes e elementares aspectos, como se buscasse em Michel Foucault e sua arqueologia "rastros deixados pelos homens, onde se tentava reconhecer em profundidade 0 que tinham sido" (FOUCAULT, 1995, p. 8). Desse modo, a matéria ficcional hatouniana é sempre moldável, não está explicitamente a serviço de nenhuma causa, mas ao mesmo tempo é visivelmente comprometida com o reconhecimento do espaço e do tempo, numa constante busca para a ressignificação dos sujeitos que construíram suas histórias no histórico conflito em que sempre viveram, em se tratando das diversidades regionais, mas acima de tudo, do confronto desigual com exploradores e mandatários, sempre a serviço dos extermínios e "silenciamentos", aos quais os habitantes da Amazônia foram subjugados ao longo de todo o seu percurso histórico.

É neste terreno multifacetado e marcado pelo fluxo de culturas e identidades "em trânsito" que o ficcionista 
Milton Hatoum vai tecendo seus personagens sempre imersos em diferentes imaginários e instigantes perspectivas na tentativa de desvelar pela recriação literária a enigmática região amazônica, suas paragens, seu povo, suas cores e suas dores. Assim se dá em Órfãos do Eldorado, objeto de estudo deste trabalho e também última produção ficcional, que ele próprio costuma chamar de "novela literária". Lançado em 2008 e ambientada em Manaus, Belém e cidades adjacentes na primeira metade do século XX.

A expressão “Órfãos do Eldorado" nos remete a secular lenda da cidade encantada, a Eldorado submersa com suas ruas ladrilhadas de ouro e seu casario resplandecente. Lá num castelo dourado repousam príncipes e princesas num sono diurno para se restabelecerem das noites de passeios aquáticos pelos rios da Amazônia em suas peles e formas de botos atiçando a curiosidade e muitas vezes o devaneio dos moradores do lugar. Lugar de geografia indefinida, mas cravada no imaginário misterioso regional, absorvido por viajantes e conquistadores europeus atiçados pelo desejo da conquista material. Órfãos, neste contexto, é a expressão que segundo o dicionário Aurélio nos conduz a compreensão das múltiplas significações possíveisàs quais aqui é aplicada. Leia-se então: 1. Quem perdeu o pai ou mãe, ou ambos. 2. Abandonado. 3. Desamparado. 4. Largado. 5. Desprezado, rejeitado. Assim, a partir dosinúmeros significados propostos, abandonado, daria conta de reunir sentidos para fundamentarmos a ideia de que a Amazônia vem sendo ao longo da história, cobiçada, devastada e espoliada e sempre abandonada, seja pelo esquecimento daqueles que por aqui passam ou pelo forçado silenciamento dos que sempre aqui estiveram numa frenética negociação de "representação identitárias" ou "trocas culturais", sempre na tentativa de construção de linguagens, discursos e diálogos com o mundo. 
o título Órfãos do Eldorado carrega uma ambiguidade instigante, se no plano da narrativa trata da estória de um órfão de família abastada nos idos tempos áureos da Amazônia, no plano discurso nos coloca no centro de uma desafiadora constatação. Esta região que durante séculos abasteceu cofres de desconhecidos aventureiros, e também o imaginário de fabulosos viajantes desbravadores, vai aos poucos deixando na orfandade seus autóctones. E o espaço privilegiado da "maior biodiversidade do planeta", continua incompreensível para seus filhos legítimos, marcados pelo "ativismo natural e estanque" que segundo Euclides da Cunha já no início do século prenunciava sobre a região "é a conservação sistemática do deserto, é a prisão celular do homem na amplitude desafogada da terra" (CUNHA, 1988, p. 95). Órfãos do Eldorado se inscreve na categoria das narrativas sobre a Amazônia que não excede o exotismo, mas privilegia o espaço, a natureza sempre “impenetrável”, "intransponível".

Aludindo a esta reflexão examinemos a capa da obra. Nela a imagem é ao mesmo tempo paradisíaca e conflitante. Permite ao leitor o olhar da câmera. Um espaço do interior de uma casa simples de madeira, à moda ribeirinha, investida de uma luz em dois planos, a parte inferior totalmente envolvida num claridão amarelo-cobre e na superior a escuridão esvaecida como o prenúncio da aurora. A visão que se tem do exterior da casa é de uma minúscula janela protegida por uma cortina de renda que destoa da simplicidade da construção. Lá fora, uma visão misteriosa de ocaso indefinido, e o rio plácido e majestoso, seguindo o seu curso natural. Com um olhar mais atento podemos relacionar elementos que corroboram para a principal motivação temática da narrativa. A "visão de fora" ali refletida é marcada por reverberações douradas no espaço, confundindo os que buscam nestas paragens a riqueza e o poder, em outro 
plano, a "visão de dentro" é de um lugar, indefinido, um misto de luz e escuridão que tudo confunde, esconde e inebria os seus possíveis sujeitos numa eterna busca por desvendar o estranhamento amazônico, marcadamente construído pelo temor e respeito ao rio, signo onipresente da cultura, da identidade e vida locais, como podemos enxergar nas palavras de Arminto:

Quando olho o Amazonas, a memória dispara, uma voz sai da minha boca, e só paro de falar na hora que a ave graúda canta Macucauá vai aparecer mais tarde, apenas, cor do céu quando escurece. Canta dando adeus à claridade. Aí fico calado e deixo a noite entrar na minha vida (HATOUM, 2008, p. 14).

Como vemos, numa linguagem altamente figurada $o$ narrador elege o rio Amazonas como elemento sinalizador das incursões do autor e da obra no universo semântico, e por isso "simbólico" do lugar - o espaço do rio é o palco onde se revela a intermitente luta do revelar/esconder no universo mitológico amazônico, e, portanto sempre presente aqui e também no imaginário cultural da gente da região.

Órfãos do Eldorado é uma história enredada nos anos de 1940, entre a Primeira e a Segunda Guerra Mundial. Sua trama conta a saga de Arminto, o pretenso herdeiro da família Cordovil que fez fortuna na Amazônia no auge do extrativismo vegetal, do frenético comércio nos rios locais e no transporte de borracha e castanha em cargueiros entre o Brasil e a Europa. Arminto evoca de vez em quando a imagem do pai Amando e do avô Edílio Cordovil, personagens ausentes, mas ao mesmo tempo reguladores do tom memorialístico que o autor imprime à obra.

O palácio branco dos Cordovil é que era uma casa de verdade. [...] Amando Cordovil seria capaz de devorar o mundo... Era um destemido: homem que ria da morte. [...] Quis apagar o passado, a fama de meu avô Edílio. Não conheci esse Cordovil. Diziam que ele ignorava o cansaço e a preguiça, e trabalhava que nem um cavalo no calor úmido desta terra (HATOUM, 2008, p. 14).

Com um misto de 
ressentimento e saudade o autor utiliza como estratégia narrativa a representação de sujeitos ligados consanguineamente, mas cingidos pelo tempo e pelas matizes culturais diferenciadas pela época de cada um. Como se vê, a construção dessas personagens que se afirmam somente no vão da memória ganham importância como forma de resistência e de sobrevivência neste cruzamento do passado com a perspectiva do presente.

Outros

personagens compõem a narrativa do romance que se divide entre dois espaços extremos: a casa de Manaus, construída numa bem cuidada chácara e o palacete branco em Vila Bela, erguido para ostentar a fantasiosa grandeza econômica de Amando, mas também, os tempos áureos da cidade mais cosmopolita do Brasil ocidental, a tal ponto de "os colonizadores confundirem Manaus ou Manoa com o Eldorado". A trama central move-se em torno de Arminto, principal personagem e também narrador, o pai
Amando, ausente por opção e a mãe morta, Angelina. Daí a relação conflituosa entre pai e filho - sempre culpado pela morte da mãe, não tem referência paterna e ainda carrega o peso da "dupla orfandade" - dada a constatação de Amando "Tua mãe te pariu e morreu" (HATOUM, 2008, p. 16) e Florita, mulher índia a quem foi confiada os cuidados da Arminto e da família na fatídica ausência materna. Os personagens secundários, mas também extremamente importantes no enredo são Estiliano, o advogado e amigo incondicional de Amando, espécie de "consciência" e substituição à figura paterna. Denísio Cão, um barqueiro conhecedor dos labirínticos rios amazônicos, Madre Carminal, a freira espanhola e missionária superiora do internato e responsável pelas órfãs desvalidas e Dinaura, menina-mulher, órfã, índia, "filha do mato" e sempre objeto de desejo de Arminto - uma espécie de salvação e perdição, figura simbólica que vagueia entre o real e o fantástico, típico 
das narrativas de configuração mítica.

Órfãos do Eldorado iniciase com relatos espaçados de um Arminto envelhecido e corroído pela bebida - "tarubá, que ganhava dos índios saterésmaués" - e assim, vai narrando as histórias que cresceu ouvindo a partir da vivência com crianças indígenas à beira dos rios e também contadas por Florita, seu elo de ligação com as tribos indígenas do lugar. Como ele mesmo afirma: "Lendas que eu e Florita ouvíamos dos avós das crianças da Aldeia. Falavam em língua geral e depois Florita repetia as histórias em casa, nas noites de solidão da infância" (HATOUM, 2008, p. 13).

Assim a narrativa

é marcada pelo esforço do narrador em resgatar retalhos de suas vivências e experiências, e acima de tudo ambientar seus personagens em um espaço povoado de reminiscências da memória e de sujeitos e suas falas "historicamente silenciadas" numa realidade construída na diversidade de línguas e num hibridismo cultural pertinente ao momento da efervescência social em que aqueles rincões amazônicos atravessavam.

0 fragmento em destaque ainda dá conta de esclarecer uma das estratégias narrativas da obra. É com o "encaixe" de algumas narrativas indígenas e suas performances, às vezes fantasmagóricas, que o autor traz para o espaço contemporâneo de "negociação de identidades", muitas vezes "conflitantes" e sempre clivadas de "identificações culturais" numpropósito que não só se faz pela estrutura, mas também pela intertextualidade. Estabelece-se, assim, um diálogo entre os planos que estruturam o romance e a perfomatização das línguas indígenas traduzidas pela personagem que se constitui como o elo entre a cultura formal e as "verdades distorcidas", mas sempre revisitadas da nativa oralidade caboclo-ribeirinha, às vezes considerada marginal e não confiável. Essa confluência de ideias, relatos históricos, passagens fictícias fazem de 
Órfãos do Eldorado um texto aglutinador das principais motivações temáticas da narrativa hatouniana.

\section{Os narradores distanciados de Hatoum}

Milton Hatoum faz sua estreia como ficcionista com o romance Relatos de Um Certo Oriente, que como o título sugere é tecido a partir de relatos intercruzados de narradores que se alternam para narrar acontecimentos ambientados em Manaus, pois as tramas giram em torno de dramas familiares de imigrantes libaneses, radicados no Brasil, mais precisamente no final do século XIX e início do século XX. O romance dá conta de reconstruir o passado de uma família que busca solidificar as "representações culturais" do oriente sem se eximir das miscigenações aparentes de seus personagens, cunhados quase sempre em trânsito entre linguagens, cidades, países e continentes.

Sua segunda obra, Dois Irmãos, prossegue na temática da imigração oriental, sua voz narrativa à maneira do romance anterior é pautada na rememoração das vivências cotidianas calcadas na incompatibilidade fraterna, bem ao gosto das "mitologias antigas", como o episódio bíblico de Caim e Abel e Esaú e Jacob. Buscando uma referência mais próxima, Hatoum inspirase em Machado de Assim para desenvolver esta narrativa bem dentro dos padrões do Realismo, onde um narrador adulto se faz "um espaço" de mediação para dá voz a "outros", quase sempre sujeitados ao infortúnio ou à luta na construção de suas identidades.

Cinzas do Norte, a terceira narrativa, volta-se para o espaço amazônico como grande espelho, onde se refletem todas as derrotas e se dá a "consumação da matéria" que forma a substância romanesca. Aqui o narrador Nael se "debruça" nos "resíduos" de um tempo passado e evocado sistematicamente nos cortes e cesuras do presente nas "vozes dissonantes" e "contraditórias" de uma sociedade que 
envelheceu repentinamente, concomitante com a queda da Manaus imponente de outrora, relegando seus habitantes à convivência desajustada e ambivalente de "memórias espaciais simultaneamente arcaicas e modernas" (CURI, 2009, p. 48).

Essas obras de Milton Hatoum e suas potenciais veredas ficcionais possuem elementos estruturais em comum que se tonam basilares. Seus narradores estão sempre a serviço de um outro personagem, como que para lhe legitimar as ideias, as verdades, as falas, as motivações e até os desejos. Visualizamos nos três romances o espaço familiar como um eixo de retorno. A "metáfora da casa" paterna está sempre presente como um fio norteador das idas e vindas do autor ao redor de si mesmo e em busca de "elos perdidos" com o mundo que o cerca, que neste caso se coloca como os espaços por onde circulam seus principais personagens "em trânsito" entre o Líbano, Manaus, São Paulo e outra vez
Manaus - como no "eterno retorno" nietzschiano - e seus arredores num "deambular" próprio dos que vivem numa insistente busca de identidade e assim se constituem como "seres de fronteira", sempre acoçados pela certeza da mobilidade de seus traços culturais.

Voltando ao romance em estudo e considerando a indicação desde aglutinar elementos primordiais da produção literária de Milton Hatoum, Órfãos do Eldorado é talhado a partir de certo distanciamento do autor das eminentes sugestões temáticas e conceituais trabalhadas em suas obras anteriores. Como num divisor de águas este romance ou novela literária - bem ao gosto de seu autor - deixa de lado a ambientação familiar libanesa e seu núcleo familiar a partir de indivíduos radicados em Manaus e envolvidos com o comércio local. Há como em Cinzas do Norte um velado escapismo do contexto oriental para mergulhar em questões sociais do Brasil naquele momento. A narrativa então é um 
misto de crônica da região onde os personagens estão à mercê dos percalços sociais vividos naquele efervescente e conturbado início de século, atravessado pelo declínio da mais promissora "empresa" nacional a exploração da Amazônia e seus recursos naturais, principalmente a extração da borracha, tida no momento como suprimento econômico fundamental para a viabilização da crise mundial que se instalava, em detrimento do contexto de guerras. Mas também uma feliz tentativa de mergulhar no "terreno mole dos mitos" e mostrar possibilidades de convivência entre mundos distintos, num entrelaçamento de saberes e práticas que resvalam entre o "simbólico e o real", o "regional e o universal".

No romance Arminto, o narrador, vive numa intensa crise existencial, desde o nascimento é rejeitado pelo pai que o responsabiliza pela morte prematura da mãe, dá-se aí uma retomada do autor a um de seus temas favoritos, a "metáfora da orfandade". Assim não tendo a referência paterna, Arminto ainda carrega o peso da ausência voluntária do pai e a perda irreparável da mãe, elementos que se conjugam para transformá-lo num indivíduo sem grandesobjetivos e vulnerável as paixões.

Arminto cresce sobre os cuidados de Florita, uma espécie de anjo protetor e sedutor, é ela quem estabelece a possibilidade de diálogo entre ele e o mundo ao seu redor. Como todos os outros narradores hatounianos, é também um ser fendido, falta-lhe tudo, principalmente legitimidade para tal. Esta pode ser também uma outra faceta em Hatoum, seus narradores vão sendo tecidos mediante a urdidura da própria narrativa. Arminto, protagonista e narrador, vai construindo o enredo mediante as histórias ouvidas em suas andanças pela zona portuária de Manaus, nos pontos comerciais de Vila Bela ou mesmo na voz "duvidosa" de Florita, quando "traduzia" as lendas contadas pelos índios velhos das aldeias próximas. $\mathrm{Ou}$ ainda, em frequentes digres- 
sões volta ao passado, à infância ou à juventude tumultuada entre os tempos difíceis de estudante em Manaus, as bebedeiras e passagens pelos cabarés e salões de navios na orgia, até se situar em Vila Bela e se deixar carcomer pela velhice ou pelo desejo por Dinaura.

Ninguém quis ouvir essa história. Por isso as pessoas ainda pensam que eu moro sozinho, eu e minha voz de doido. Aí tu entraste para descansar na sombra do jatobá, pediste água e tiveste paciência para ouvir um velho. Foi um alívio expulsar esse fogo da alma. A gente não respira no que fala? Contar ou cantar não apaga essa dor? Quantas palavras eu tentei dizer para Dinaura, quanta coisa ela não pode ouvir de mim (HATOUM, 2008, p. 103).

Milton Hatoum situa seu personagem-narrador no tempo da narrativa, a construção do enredo se dá pelas fases da vida de Arminto - inicia-se na infância, desenvolve-se na juventude e vida adulta e termina com este, envelhecido, mas vigoroso o bastante para questionar o questionar-se frente ao exercício doído da narração ou escritura, ou ainda no dizer de
Maria Zilda Curi "ele explicita sua estratégia narrativa revelando-a como a junção frágil de fragmentos que mimetiza as trilhas imprecisas da lembrança..." (CURI, 2007, p. 85).

É também pelo olhar de Arminto que Hatoum vai tecendo o retrato da devastação que este personagem condiciona. A paixão avassaladora que nutre por Dinaura o leva a destruição e com ele, uma atmosfera de declínio se instala nos principais espaços que formatam a ambientação do romance. Manaus, Vila Bela e Brasil se tornam em ruínas, estão decadentes, devastadas, sequiosas de justiça e, portanto, órfãos - de poder público, de cultura e de identidade. Na verdade, trava-se uma luta, como no dizer de Zygmunt Bauman, "a identidade é uma luta simultânea contra a dissolução e a fragmentação..." (BAUMAN, 2005, p. 84). Na narrativa de Hatoum, Manaus, a "cidade personagem" outrora celebrada é agora palco de transformação, onde seus habitantes resistem à diluição de suas referências identitárias, alteradas pelo 
abuso da autoridade policial, a supervalorização das "taxas alfandegárias", a queda no "movimento portuário" e falta de perspectivas políticas e, principalmente, a "especulação comercial" em torno da demolição de antigas construções, para dar lugar a emergente "modernidade" na selva.

Vives em outro mundo, disse Estiliano. Sai desta chácara e anda pela cidade. Andei de bonde pela cidade, vi palafitas e casebres no subúrbio e na beira dos igarapés do centro, e acampamentos que dormiam ex seringueiros; vi crianças serem enxotadas quando tentavam catar comida ou esmolar na calçada do botequim Alegre, da Fábrica de Alimentos Italianos e dos restaurantes. A cadeia da Sete de Setembro estada lotada, vários sobrados e lojas à venda (HATOUM, 2008, p. 57).

A cidade de Manaus é aqui retratada através de uma imagem que se distancia dos seus grandes momentos de glória e poder. Se iguala a qualquer "zona de pobreza" em qualquer "lugar periférico" do mundo. 0 narrador elenca uma gama de sujeitos e suas mazelas, sejam elas econômicas, sociais e éticas. Tais sujeitos são herdeiros culturais dos verdadeiros nativos, aqueles para quem todas as benesses do poder deveriam ser resguardadas, mas são transformados em seres "chagados" e empobrecidos tal qual a cidade. Aí então a Manaus "terrena e miserável" se opõe a Manaus "submersa e encantada" que sempre povoou o imaginário local, e onde se imagina um lugar onde reina a riqueza, a paz e a justiça.

Para se contrapor a Arminto, personagem a quem é confiada a narração do romance, temos Dinaura, objeto de desejo do protagonista que se configura como mulher inacessível, presente em quase toda a trama, como um fio condutor das ações do narrador, é pela ausência que se faz revelar sua natureza arcana. Uma espécie de mulher e de miragem, realidade e sonho, índia "filha do mato" e entidade mitológica.

Quando Estiliano me ouviu falar de Dinaura, desdenhou: Essa é boa, um Cordovil embeiçado por uma mulher que veio do mato. E Florita sem conhecer a órfã, disse que $o$ olhar dela era só feitiço: parecia uma dessas loucas que 
sonham em viver no fundo do rio. 0 olhar de Dinaura era o que mais me atraía. Às vezes um olhar tem a força de um desejo. Depois o desejo cresce, quer penetrar na carne da pessoa amada. Eu queria viver com Dinaura e adiei essa decisão até o limite da vaidade (HATOUM, 2008, p. 31).

Dinaura, a extraordinária imagem feminina criada por Hatoum, se coloca no texto como um enigma, todas as vontades, buscas e aspirações de Arminto as conduzem para ela. Suas realizações pessoais estão todas vinculadas à possibilidade da realização amorosa e da satisfação carnal. Arminto é um personagem marcado pela ausência, o não conhecimento da mãe e o castigo imposto pelo pai lhe transforma em um homem ambíguo, "exilado da casa paterna", e assim, peregrino de uma eterna busca de realizações. Dinaura catalisa para o interior da trama com sua "existência contraditória" um vasto campo de intersubjetividades, figurando-se em dois planos distintos. No primeiro plano nos remete a ilustrativa imagem "da alegoria desenhada por Jan van der Straet", que ilus- tra a capa da obra $A$ Escrita $d a$ História, de Michel de Certeau - ali a índia América, nua reclinada numa rede, com a mão estendida como a acolher em seu regaço Américo Vespúcio, o descobridor. Dinaura seria essa "índia-mulher" que oferece ao "estrangeiro" seu corpo, suas marcas, suas dores produzidas pela também orfandade imanente, pois sua condição de mídia, órfã e protegida das religiosas carmelitas, lhe transforma em ser onde coexistem vários outros seres, culturas, traços identitários, daí sua performance sempre evasiva num movimento de infinitas "aproximações e distanciamentos".

As órfãs do Sagrado Coração de Jesus também estavam no Cemitério, todas juntas, com o mesmo traje: saia marrom e blusa branca. Meninas. Uma delas tinha jeito de moça crescida. Parecia uma mulher de duas idades, usava um vestido branco e olhava para o alto como se não estivesse ali, como se não estivesse em lugar nenhum. De repente o olhar me encontrou e o rosto anguloso me sorriu (HATOUM, 2008, p. 28).

Na cena descria o narrador o usando de evidentes sutile- 
zas vai desvelando a atmosfera misteriosa que envolve o relacionamento fortuito dos protagonistas. 0 primeiro encontro foi justamente no enterro de Amando, o pai disciplinador, que morre nos braços de Arminto, no dia do grande encontro que teriam. Ela já aparece estigmatizada a suprir a falta deixada pela morte do pai. Na escolha das expressões Milton Hatoum vai pontuando a atmosfera misteriosa que deseja imprimir na aventura insorte dos amantes, como é comum nas narrativas míticas. Em "Parecia uma mulher de duas idades", "usava um vestido branco" e "como se não tivesse ali, como se não tivesse em lugar nenhum" temos a construção da personagem labiríntica de Dinaura que não se revela pelos traços físicos, veste-se da representação da pureza e ainda do jogo mimético da ausência/ presença.

No segundo plano Dinaura é elevada ao patamar das outras metáforas em que o autor fundamenta a sua obra. Eldorado, o cargueiro alemão e principal herança de Arminto, naufraga e com ele seus sonhos de vida boa, pois ali se esvai toda a fortuna acumulada pelo pai ao longo de toda a vida. Eldorado, a "cidade submersa"e encantada no fundo do rio é tão maravilhosa quanto inacessível e Dinaura que se constitui na amante enigmática, pois ao mesmo tempo que se deixa possuir numa ardente cena de amor, desaparece na atmosfera espessa do sonho.

Numa tarde de dezembro cheguei mais cedo à praça, deitei no banco morno e dormi. Quando as cinco badaladas me despertaram, o rosto de Dinaura surgiu contra o sol. Não tive tempo de perguntar sobre a dança nem para me erguer: vi os olhos pretos, grandes e assustados. Podia ser um sonho? Mas eu não queria sonho, desejava a mulher ali sem ilusões. Então acariciei a boca de Dinaura, senti a respiração a respiração inquieta, o tremor e o suor nos lábios abertos que roçavam meu rosto. No prazer do beijo senti uma dentada feroz. Soltei um grito, mais de susto que de dor. Tentei falar, minha língua sangrava. Na confusão, Dinaura escapou (HATOUM, 2008, p. 47).

Ou seja, as representações 
de Eldorado/Manaus e Dinaura confluem para a macro metáfora desenvolvida na obra numa correspondência paralela entre esses símbolos. Dinaura catalisa para si essa semântica "simbólica do lugar", espaço de busca implícita de identidade desenhada pela dinâmica mítica na urdidura da obra.

As figuras femininas em Órfãos do Eldorado detêm o poder de dominar e determinar o destino dos homens, bem ao gosto do Realismo. Ora os levam ao delírio, ora ao total fracasso. Florita é uma dessas figuras de destaque na obra. É a única voz feminina que se faz ouvir, pois Angelina está morta e Dinaura é silenciada pela sua condição "inferior". Florita é a "propulsora" da narrativa, mulher índia, moça, uma espécie de serviçal da família. Dela pouco se sabe, nunca casou, nem teve filhos. Criou Arminto com o desvelo materno, mas também lhe proporcionou sua iniciação sexual. Num misto de ama e amante ela se caracteriza como personagem central do enredo, pois carrega em si todos os segredos da família, determina as atitudes dos outros personagens e ainda prescruta os desejos mais recônditos de Aminto. Ela não se impõe, mas sabe como conduzir os destinos de todos.

Assim é a descrição no romance da chegada de Florita, uma nativa que estudou e recebeu um batismo cristão, como aponta o fragmento abaixo:

Pobre e corajosa, dizia Amando. Não quis fugir com os preguiçosos, largou a família para trabalhar é viver melhor. Meu pai levou a moça para o palácio Branco e lhe comprou roupa e sandálias. Em Vila Bela estudou e ganhou um nome, com batismo cristão, festejado (...).Essa moça me criou. A primeira mulher na minha memória. Florita. Anos depois, também em Vila Bela, uma tarde em que ela dormia na rede, entre no quarto e fiquei observando o corpo nu. Tive um susto quando ela se levantou, tirou minha roupa, me levou para dentro da rede (HATOUM, 2008, p. 69).

Aqui observamos como Florita foi capturada e introduzida na família "branca", deixando para trás seus familiares, seu espaço natural, "exilada" de suas raízes justamente no seu lugar de origem. Arminto 
e Florita são sujeitos díspares, ele descendente de uma família tradicional e ela indígena, deslocada de sua cultura. 0 sentido ambíguo que estas cenas oferecem é justamente a coexistência pacífica e às vezes até complementar desses sujeitos em "trânsito", marcados principalmente pelo fenômeno da miscigenação de valores locais. Proteger e seduzir são ações atribuídas à Florita, que se configura em mais uma metáfora da Amazônia ou da lendária Eldorado encantada.

Ainda metaforicamente retratada, Florita acompanha a glória e o declínio da família Cordovil, ela está tão inserida no contexto familiar que é também brutalmente atingida. A degradação de Manaus se reflete no efetivo empobrecimento de Arminto que a conduz para a miséria e a morte.

A tristeza que senti naquela tarde começou no meio da manhã. Eu colhia jambos rosados quando um homem apareceu. Empurrava bem devagar o tabuleiro de Florita... Fui ver o que ele queria e vi minha Flor deitada no tabuleiro. Domingo no sol? Perguntei.O homem tirou o chapéu e disse: Acordou morta (HATOUM, 2008, p. 94).

Pela voz do narrador tem-se a constatação da morte anunciada de Florita. Carregando no próprio as marcas dos embates sociais, as incursões históricas e das definições identitárias que marcaram a Amazônia em seu processo de "assimilação" da modernidade.

A morte de Florita pode ser também considerada como o fim de um ciclo. Ela simbolizava a infância desamparada, a abonada vida adulta e agora a velhice desmemoriada. Arminto, o narrador e personagem protagonista "inscreve no próprio corpo" o dualismo homem/lugar, as duas faces de uma mesma motivação. "A morte de Florita rompeu os laços com o passado. Eu, sozinho era o passado e o presente dos Cordovil. E não queria futuro para homens da minha laia. Tudo vai acabar neste corpo de velho" (HATOUM, 2008, p. 94).

A imagem aqui retratada é de um Arminto velho, cansado pela idade, e agora convencido de sua condição simbólica, era ele mesmo passado e presente, 
sem perspectiva de futuro. Esta sua visível decadência corresponde metaforicamente ao já prenunciado empobrecimento de toda uma região. Nessa Amazônia que Arminto tão bem representa há inexoravelmente a ausência de tudo, suas características pessoais e familiares se dissolveram com as constantes perdas materiais e amorosas e com elas suas marcas culturais e suas constantes lutas internas para resguardar o que sobrou de sua estilhaçada identidade, como diria Edward Said, "a maneira como formulamos ou representamos o passado, molda nossas concepções do presente" (SAID, 2011, p. 36). Em Órfãos do Eldorado o autor estabelece uma atmosfera de contradições, de movimentos lacunares e propõe aos principais personagens um vaguear em terrenos movediços como se estivessem numa eterna construção/desconstrução de suas matrizes culturais.

A obra de Milton Hatoum é marcadamente carregada de sentidos. Ele transfere para suas narrativas seu espírito aventureiro e questionador e busca por desvendar suas próprias matizesculturais. Seu texto é vigoroso e sugere sempre outras possibilidades de "construção de identidades". Sua origem libanesa lhe qualifica a construir personagens a partir das várias impressões que recolhe em suas andanças e incursões em outras culturas e realidades. A construção de suas personagens obedece a um ritual quase sempre cadenciado, são geralmente sujeitos híbridos, de caráter duvidoso, "desterritorializados", órfãos, são seres que revelam a negociação de "novas identidades" e diferentes "linguagens culturais".

As considerações conferidas à narrativa Órfãos do Eldorado até aqui, foram uma tentativa de dizer das possibilidades de leituras sugeridas pelo autor e das motivações temáticas empreendidas no texto. Numa leitura mais verticalizada pode-se chegar a outras interpretações, que se deixam esconder nas antagonias criadas pelas emblemáticas imagens da Amazônia e suas "estruturas discursivas" e a "cidade encantada" de Eldo- 
rado, que vão sendo aos poucos encobertas por outras construções literárias bem arquitetadas e elaboradas e também revestidas de vários outros sentidos. Hatoum se propõe então a reafirmar as palavras de Larrosa: "A literatura, repito, é uma experiência de linguagem na qual o que está em jogo é o que escrever. Daí a permanente tentação e a permanente ameaça do silêncio" (LARROSA, 2004, p. 352).

Pelo olhar de Larrosa, percebe-se que a "experiência da linguagem" empreendida por Hatoum em sua narrativa é altamente marcada por uma escrita calcada na diversidade e a construção de seus personagens, a escolha vocabular, a forte adjetivação e a determinação de um narrador homodiegético que com sua voz "lacunar" silencia todas as outras possibilidades do convívio linguístico. Em Órfãos do Eldorado há uma implícita sugestão à impossibilidade das manifestações da linguagem, seja de forma oral ou escrita, o que poderia ser uma celebração, se torna uma cisão no terreno linguístico da obra, empreendida por um narrador que conduz toda a narrativa de uma "plataforma divina". As "vozes" no texto estão sempre em terceira pessoa, como se insistissem em não serem ouvidas, mas sempre pronunciadas.

A voz da mulher atraiu tanta gente que fugi da casa do meu professor e fui para a beira do Amazonas. Uma índia, uma das tapuias da cidade que falava e apontava o rio. Não lembro o desenho da pintura no rosto dela; a cor dos traços, sim: vermelha, sumo de urucum (HATOUM, 2008, p. 11).

Portanto, fica claro neste fragmento a ausência da manifestação da língua indígena, o autor nos retira a oportunidade desta convivência ou experiência com outras línguas e outras culturas. Mesmo assim a discussão sobre a identidade sugerida por Hatoum não está prejudicada, ela é uma necessidade constante em sua narrativa. Há em seu texto uma relativa busca por elementos que se constituem como propulsoras forças determinadas a construir e reconstruir esses sentidos que formulam as mais diferentes 
identidades disseminadas em sua obra.

Para o crítico Zigmunt Baumam "nascida como ficção, a identidade precisava de muita coerção e convencimento para se consolidar e se concretizar numa realidade (...)" (BAUMAM, 2005, p. 26). Neste sentido a natureza ficcional da identidade por si só já se constitui num conceito "frágil" e "eternamente provisório" e a ficção enquanto objeto de realização da atividade linguística concretiza com uma certa autonomia num terreno fértil de vivências e trocas identitárias. Assim os sujeitos em trânsito nas narrativas hatounianas representam aqueles que buscam nos espaços mais díspares da sociedade a utópica "segurança" de "ser identificado".

Órfãos do Eldorado além destes e de outros contextos aqui relacionados, ainda nos aponta para um Brasil que nos parece tão próximo e distante, uma Amazônia que é ao mesmo instante nosso habitat natural e tão logo, um indecifrável enigma a nos desafiar. Nessa perspectiva Eni Orlandi contribui para esta reflexão quando diz: "Procuramos nos conhecer, conhecendo como a Europa conhece o Brasil" (ORLANDI, 1990, p. 19). É que o reconhecimento cultural só se dá pelo conhecimento de outros "discursos" e de outros "trânsitos" e de outras práticas. A arquitetura da narrativa hatouniana é sim esta movimentação compulsória para as entranhas do Brasil, pois resvala em elementos fundantes de nossa nacionalidade, dessa "mistura" que nos determina.

Em sua obra Natureza $e$ cultura no Brasil (1870-1922), Luciana Murari (2009) enfatiza que a produção literária do final do século XIX e início do século XX já estava fortemente marcada por estas visões de "redescoberta" que se percebe em Hatoum, os escritores da época fundamentavam seus textos em reminiscências da memória, mais precisamente em motivações que evocavam a infância e o saudosismo do passado.

0 culto a tradição e a nostalgia evocada pela cisão da linha de continuidade entre presente 
e passado tornaram-se, assim, elementos recorrentes do imaginário romântico, criando uma linguagem marcada pela dificuldade de simbolização de uma realidade que se desfazia em ritmo acelerado. A recuperação empática do passado pela produção cultural poderia eliminar a busca da identidade e escrever a história que possibilitaria restabelecer a articulação orgânica entre o indivíduo e o grupo (MURARI, 2009, p. 191).

Por ser cronologicamente inscrito entre os autores pós-modernos a obra em estudo não foge aos traços da escritura memorialista, Hatoum vai beber em fontes românticas e finca sua ficção em elementos reconhecidamente plasmados na memória. Ali se vê o "cultoda tradição nostálgica" tão nitidamente que "presente x passado" se transmutam em recorrência a outras espacialidades. Para configuração do tempo volta-se a "ancestralidade mítica", o que se constitui como um artifício para articular ainda mais a "recuperação empática do passado" e a constante busca dos sedimentos da identidade nacional.
Já em Antônio Cândido, e sua obra Literatura e Socieda$d e$, parte do paradoxo de que "o inferior é superior", ou seja, "as nossas deficiências, supostas ou reais, são reinterpretadas como superioridades" (CÂNDIDO, 2000, p. 110). O nosso mais reconhecido teórico e crítico literário defende a tese de que nossa cultura é acima de tudo paradoxal: somo um "povo latino", nossa "herança cultural" é europeia e nossa matriz étnica é mestiça, além das influências de raças "primitivas", "ameríndias" e "africanas". Hatoum se abastece de todas essas informações e eleva seus "falhos heróis" a categoria de sujeitos superiores, sempre imbuídos a contribuírem para amenizar nossas contradições culturais. Em suas obras vai "sobrepondo geografias, entrecruzando identidades e ajustando vivências", num esforço ostensivo de revelar "experiências comuns" na voz de narradores carregados de sugestões simbólicas, construções metafóricas e possibilidades de reconhecimento de si e do outro. 
Considerando as leituras e pesquisas realizadas, comungo com Mikhail Bakhtin quando afirma que "ver e compreender o autor de uma obra significa ver e compreender outra consciência, a consciência do outro e seu mundo, isto é, outro sujeito" (BAKHTIN, 2011, p. 316). Parece simples, mas o que quer o teórico russo pode nos conduzir para o cerne das narrativas hatounianas, neste exercício de "compreensão" mútua autor/ leitor de sua linguagem e de um mergulho profundo em suas raízes ideológicas, políticas e morais. Seu olhar ao mesmo tempo contemplativo e crítico é o guia pelas margens e paragens de suas obras, que se revestem de encantamento e concretude nas "travessias" literárias e "culturais" empreendidas por sua tenaz escrita.

Milton Hatoum, em seu Órfãos do Eldorado, elabora uma espécie de obra-reflexo de seus mais peculiares traços estilísticos. 0 ambiente é a Amazônia, a cidade é ora Manaus, ora Belém. 0 tema central é a sempre revisitada divergência paterna, o rancor entra pai e filho, num misto de desprezo e amor reprimido. Tudo isso acentuado pela atmosfera mitológica. Este romance traz para à discussão o autor Milton Hatoum e suas performances da "Amazônia enquanto criação discursiva" (CARVALHO, 2005, p. 23) e suas incursões no universo cultural desta região. Posicionado como um "migrante" sua descendência libanesa só acrescenta sobriedade a sua peculiar forma de decodificar esse universo tão enigmático e ao mesmo tempo exposto a tantos "rótulos" e "interesses". Hatoum se auto define como um ficcionista "que tenta imaginar a sua história, reconstruí-la e retornar ao que já não existe mais" (REVISTA MAGMA, USP). E é neste construir e reconstruir que nosso escritor vem se colocando como uma das grandes vozes do cenário literário brasileiro e da nossa prosa de ficção contemporânea.

\section{Referências}

BAKHTIN, M. Estética da criação verbal. Prefácio à edição francesa Tzvetan Todorov; introdução e tradução do russo Paulo Bezerra. 
- 6. ed. - São Paulo: Editora WMF Martins Fontes, 2011.

BAUMAM, Z. Identidade: entrevista a Benedetto Vecchi. Tradução de Carlos Alberto Medeiros. - Rio de Janeiro: Jorge Zahar Ed., 2005.

CARVALHO, J. C. Amazônia revisitada: de Carvajal a Márcio Souza. Rio Branco: EDUFAC, 2005. (Série Dissertações e Teses - 3).

CERTEAU, M. A invenção do cotidiano: 1. Artes de fazer. Tradução de Ephraim Ferreira Alves. 21 ed. - Petrópolis, RJ: Vozes, 2014.

CRISTO, M. L. P. (Org.). Arquitetura da memória: ensaios sobre os romances Relatos de um Certo oriente, Dois Irmãos e Cinzas do Norte de Milton Hatoum. Editora da Universidade Federal do Amazonas.

FOUCAULT, M. A arqueologia do saber. Tradução de Luiz Felipe Baeta Neves. - 4. ed. - Rio de
Janeiro: Forense Universitária, 1995.

LARROSA, J. Linguagem e educação depois de Babel. Tradução por Cynthia Farina. Belo Horizonte: Autêntica, 2004. MURARI, L. Natureza e cultura no Brasil. São Paulo: Alameda, 2009. ORLANDI, E. P. Terra à vista Discurso do confronto: Velho e Novo Mundo. 2. ed. - Campinas, SP: Editora da UNICAMP, 2008.

RAVETTI, G.; CURY, M. Z.; ÁVILA, M. (Orgs.). Topografias da cultura: representação, espaço e memória. - Belo Horizonte: Editora UFMG, 2009. 184 p. (Invenção)

SAID, E. W. Cultura e imperialismo. Tradução de Denise Bottmann. - São Paulo: Companhia das Letras, 2011. SILVA, E. M. Entre cinzas e vozes: figurações das amazônias em Milton Hatoum e Vargas Llosa. Rio Branco (AC): PPGLI/UFAC, 2011 (Dissertação de Mestrado).

Data de recebimento 31/07/2016

Data de aceite 3/2/2017 